удк 352.071

DOI: https://doi.org/10.32851/2708-0366/2021.9.3

Тітов Д.В.

аспірант,

Вінницький національний аграрний університет

ORCID: https://orcid.org/0000-0002-0112-6663

Titov Denys

Vinnytsia National Agrarian University

ORCID: https://orcid.org/0000-0002-0112-6663

\title{
НЕОБХІДНІСТЬ РОЗВИТКУ СІЛЬСЬКИХ ТЕРИТОРІАЛЬНИХ ГРОМАД В УКРАЇНІ
}

\author{
THE NECESSITY FOR THE DEVELOPMENT \\ OF RURAL TERRITORIAL COMMUNITIES IN UKRAINE
}

\begin{abstract}
Стаття присвячена оиінюванню стану реалізації реформи децентралізаиії державного управління, спрямованої на забезпечення пери за все фінансової і сочіальної самодостатності об'єднаних територіальних громад. Проаналізовано показники розвитку об'єднаних територіальних громад і визначено основні джерела їх фінансування. Досліджено особливості функиіонування сільських територіальних громад, проблеми та чинники їх життєдіяльності. Особливу увагу приділено сільським територіальним громадам у Вінницькій області. Наукове дослідження слугує як практичним, так і теоретичним прикладом формування фінансової спроможності громад $і$ дасть їм змогу оптимізувати проиес наповнення місцевих бюджетів достатніми обсягами фінансових ресурсів, котрі необхідні для їх нормального функиіонування та розвитку сільських територій.
\end{abstract}

Ключові слова: об' 'днана територіальна громада, децентралізація, місиеве самоврядування, бюджетна дещентралізація, власні доходи, місиеві бюджети, загальний фонд місиевих бюджетів.

Статья посвящена оцениванию состояния реализаиии реформы децентрализации государственного управления, направленной на обеспечение прежде всего финансовой и соииальной самодостаточности объединенных территориальных общин. Проанализированы показатели развития объединенных территориальных общин и определень основные источники их финансирования. Исследованы особенности функционирования сельских территориальных общин, проблемы и факторы их жизнедеятельности. Особое внимание уделено сельским территориальным общинам в Винницкой области. Научное исследование служит как практическим, так и теоретическим примером формирования финансовой состоятельности общин и даст им возможность оптимизировать процесс наполнения местных бюджетов достаточными объемами финансовых ресурсов, которые необходимы для их нормального функционирования и развития сельских территорий.

Ключевые слова: объединенная территориальная община, децентрализация, местное самоуправление, бюджетная децентрализация, собственные доходы, местные бюджеты, общий фонд местных бюджетов.

The article is devoted to the assessment of the state of implementation of the decentralization reform of public administration, aimed at ensuring, first of all, the financial and social selfsufficiency of the united territorial communities. The development of the regional economy, as well as the implementation of decentralization reform, is priority areas for the current government. During the period since the beginning of the reform, certain results have been achieved, in particular, the profitability of local budgets has increased significantly, and a number of regulations have been adopted in this area. However, despite all the positive results of the reform, the established organizational and economic mechanism for the development of rural territorial communities is not ideal and needs to be improved to ensure further development in the already formed rural united territorial communities. The purpose of the study is to identify problematic issues of development of rural territorial communities, as well as to highlight the need 
to improve public policy measures aimed at promoting community support and their capacity for development in the future. In writing the article used general scientific research methods such as analysis, synthesis and generalization; in particular, they were used in the division of communities into categories, determining the level of their refinement and profitability. The indicators of development of the united territorial communities are analyzed and the main sources of their financing are determined. Peculiarities of functioning of rural territorial communities, problems and factors of their vital activity are investigated. Special attention is paid to rural territorial communities in Vinnitsa region. This research serves as both a practical and theoretical example of building the financial capacity of communities and will allow them to optimize the process of filling local budgets with sufficient financial resources needed for their proper functioning and development of rural areas, in particular. Guaranteeing financial capacity will allow the community to develop confidently in the future and accelerate the process of solving existing problems.

Key words: united territorial community, decentralization, local self-government, budget decentralization, own revenues, local budgets, general fund of local budgets.

Постановка проблеми. Останніми роками в Україні відбулися фундаментальні зміни системи місцевого самоврядування щодо місцевих бюджетів, спрямовані на створення об'єднаних територіальних громад із можливістю розширення джерел фінансових ресурсів та можливостей розвитку територій, що є стимулом покращення добробуту сільських мешканців. Фінансова забезпеченість та наповненість бюджетів сільських територіальних громад $є$ запорукою соціально-економічної стабільності та гарантією розвитку регіону.

Аналіз останніх досліджень і публікацій. Проблеми розвитку сільських територій, формування фінансової спроможності об'єднаних територіальних громад в Україні досліджуються такими науковцями та практиками, як О. Василик, О. Кириленко, В. Кравченко. Названі вчені вивчали процес формування, виконання місцевих бюджетів, а також проблеми міжбюджетних відносин. Теоретичні основи місцевого самоврядування, територіальних громад та їх розвитку висвітлені в працях О. Мороза. Питання бюджетної децентралізації, забезпечення фінансової спроможності та розвитку об'єднаних територіальних громад висвітлюються в працях О. Сунцової, Н. Ткаченко, Т. Куценко. Однак, незважаючи на наявні розробки в цій сфері, актуальними залишаються дослідження ефективності діяльності об'єднаних територіальних громад для забезпечення розвитку сільських територій в поточному періоді і на перспективу.

Формулювання цілей статті. Мета статті полягає в дослідженні проблемних питань розвитку сільських територіальних громад та необхідності вжиття заходів державної політики щодо підтримки їх спроможності стосовно розвитку на перспективу.

Виклад основного матеріалу. За останні роки в українському селі відбулися значні зміни в результаті проведення структурних економічних реформ, а саме реструктуризації земельних і майнових відносин, створення юридично-правової бази ринкової економіки шляхом приватизації землі, майна та використання індивідуально-сімейної і колективної праці. Однак під час проведення реформ першочергова увага приділялась розвитку аграрного виробництва й відповідних виробничих відносин, тоді як питанням формування й розвитку сільської поселенської мережі відводилась другорядна роль за залишковим принципом. Зрештою, це привело до занепаду села, що характеризується скороченням чисельності населення, негативною демографічною ситуацією, зростанням безробіття, руйнацією соціальної сфери. У ситуації, що склалась, вирішити проблеми розвитку сільських територій можна лише шляхом запровадження дієвої державної політики. Одними з напрямів такої політики є децентралізація влади, створення та організація роботи сільських об'єднаних територіальних громад [1, с. 7].

Відмінністю категорії «сільська територіальна громада» від інших (селищна, міська) є те, що вона характеризується певними самобутніми аспектами розвитку, 
територіальними особливостями, відрізняється кількістю членів, інфраструктурним розвитком та обмеженими економічними можливостями території.

В Конституції України (статті 140-143) [2] зазначено, що «територіальна громада - це жителі одного чи декількох населених пунктів, які добровільно об'єднуються в одну територіальну громаду для вирішення питань місцевого значення, а саме обирають сільського, селищного чи міського голову, який очолює виконавчий орган ради та головує на засіданнях виконавчого комітету та ради, старост та депутатів ради, які представляють та захищають інтереси всієї громади; управляють майном, що $\epsilon$ в комунальній власності; затверджують програми соціально-економічного та культурного розвитку і контролюють їх виконання; затверджують бюджети відповідних адміністративно-територіальних одиниць і контролюють їх виконання; встановлюють місцеві податки і збори відповідно до чинного законодавства».

В Указі Президента України «Про заходи щодо впровадження Концепції адміністративної реформи в Україні» [3] наводиться таке визначення: «територіальна громада - спільнота мешканців, жителів населених пунктів (сіл, селищ, міст), об'єднана загальними інтересами власного життєзабезпечення, самостійного, в межах законів, вирішення питань місцевого значення як безпосередньо, так і через органи місцевого самоврядування».

Енциклопедія державного управління [4] трактує територіальну громаду як «спільноту людей, об'єднаних різноманітними стійкими формальними та неформальними зв'язками, які обумовлені спільним проживанням у межах села, селища, міста».

Отже, в основі цієї категорії лежить спільне проживання мешканців, які мають загальні інтереси й здатні вирішувати проблемні питання місцевого значення через наділення їх відповідними функціями, правами і обов'язками відповідно до чинного законодавства.

Метою об'єднань громад на рівні селищ, сіл та міст $є$ досягнення спроможності більш ефективно функціонувати у фінансовому, соціальному та економічному середовищі, оскільки малорозвиненість регіонів та низька забезпеченість ресурсами окремих громад не дає можливості їм розвиватися самостійно на тому ж рівні, що інші. Формування спільного бюджету об'єднаних територіальних громад дає змогу збільшити фінансовий потенціал територій, що сприятиме їх ефективному розвитку.

Пріоритетним напрямом діяльності громад $є$ формування стратегічного бачення розвитку громади, визначення конкурентних переваг, планування соціально-економічних процесів на середньо- та довгострокову перспективу, передбачення можливих наслідків від реалізації таких цілей та завдань.

Процес євроінтеграції України зумовлює необхідність реформування різних галузей та спирається на наявні економічні, соціальні та політичні чинники впливу. Нині значна увага приділяється подоланню проблем регіонального розвитку та запровадженню процесу децентралізації влади, що дало більше повноважень та можливостей для місцевих органів влади, зокрема сільським громадам щодо прийняття рішень iз використання бюджетних коштів, соціально-економічному розвитку територій та оптимізації діяльності підприємництва в регіонах.

Проведення реформи місцевого самоврядування, що реалізується в Україні, має на меті децентралізацію влади та розмежування повноважень між різними ії рівнями задля забезпечення фінансової, соціальної, політичної та енергетичної самодостатності територіальних громад.

Термін «децентралізація» широко використовується в економічних джерелах.

В політичному сенсі децентралізація (лат. "de" - «заперечення», “centralize” «центральний») розглядається як спосіб територіальної організації влади, за якого держава передає право на прийняття рішень із визначених питань або у визначеній сфері структурам локального або регіонального рівня, що не належать до системи виконавчої влади і $є$ відносно незалежними від неї [1, с. 11]. 
Реформа децентралізації повноважень та розподілу ресурсів органів державної влади в Україні, зокрема, спрямована на інклюзивне зростання й відновлення соціальної справедливості шляхом розв'язання таких соціально-економічних проблем, як усунення нерівності доходів між сільськими та міськими домогосподарствами; подолання суттєвого розриву в якості освітніх послуг і під час формування стартового трудового потенціалу сільської і міської молоді; унеможливлення подальшого соціального відчуження окремих категорій сільських жителів; недопущення незворотності демографічної кризи та масової міграції сільського населення, що приводить до обезлюднення сільських територій [5, с. 53].

Реформа децентралізації розпочалася в Україні у 2014 р., а станом на 16 липня 2021 р. було створено 1470 об’єднаних територіальних громад, 8065 старостинських округів, з яких найбільша частка (57\%) має чисельність населення від 500 до 1800 осіб; $21 \%$ - із чисельністю від 1500 до 3000 осіб; $15 \%$ - із чисельністю населення до 500 осіб, а найменша частка (7\%) - із чисельністю населення понад 3000 осіб. Фінансова спроможність об'єднаних територіальних громад визначається їх власними доходами в загальному фонді місцевих бюджетів (рис. 1).

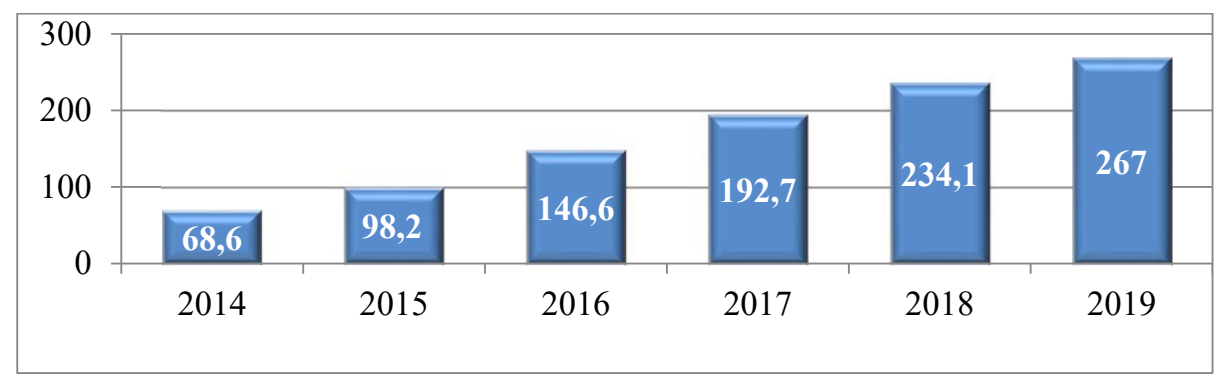

Рис. 1. Власні доходи загального фонду місиевих бюджетів, млрд. грн.

Джерело: сформовано автором на основі джерела [6]

У 2019 р. обсяг власних доходів склав 267 млрд. грн., що на 32,9 млрд. грн., або на 14,1\%, більше порівняно з 2018 р. 3 початку реформи фінансової децентралізації доходи місцевих бюджетів показують стрімку позитивну динаміку, вони виросли на 198,4 млрд. грн., що засвідчує підвищення фінансової спроможності громад.

Встановлено, що зі зростанням кількості ОТГ зростає кількість населення, що проживає на їх території. Станом на 1 травня 2019 р. кількість населення, що проживають на території об'єднаних територіальних громад, становить 9,5 млн. осіб, або 27,0\% від загальної чисельності населення в Україні.

Від результатів реалізації реформи децентралізації залежить добробут населення країни, що створює додаткову відповідальність для державних і місцевих органів влади та інших органів самоврядування в новостворених об’єднаних територіальних громадах.

Станом на 16 липня 2021 р. у Вінницькій області створено 63 територіальні громади, серед яких 24 (38,1\%) сільських, 18 (28,6\%) міських та 21 (33,3\%) селищних територіальних громад. Найбільше у Вінницькій області створено сільських територіальних громад, які за площею $є$ різними, а їх розмір коливається від 86,1 км² (Агрономічна сільська громада у Вінницькому районі) до 611 км² (Уланівська сільська громада у Хмільницькому районі). Різною є кількість рад, що об’єдналися, зокрема, від найменших за кількістю - 4 (Агрономічна у Вінницькому районі і Кунківська у Гайсинському районі) до найбільших - 14 (Уланівська у Хмільницькому районі, Літинська у Вінницькому районі). 
Найбільшими за наявністю населення в об’єднаних сільських територіальних громадах Вінницької області є Літинська (21 449 осіб), Якушинецька (16 349 осіб) Вінницького району і Уланівська (15 634 особи) Хмільницького району сільські територіальні громади, а найменшими - Бабчинецька (5 354 особи) Могилів-Подільського району, Війтівецька (5 490 осіб) Хмільницького району та Студенянська (5 911 осіб) Тульчинського району Вінницької області [7].

Аналізуючи показники бюджетів сільських територіальних громад Вінницької області в 6 районах, доходимо таких висновків. Доходи загального фонду на 1 мешканця (середнє значення) найвищими $є$ у сільських територіальних громадах Вінницького району (1 176,3 грн.), а найменшими - в Жмеринському районі (506,9 грн.). Видатки загального фонду на 1 мешканця є найвищими в Хмільницькому районі (1 644,6 грн.), а найнижчими - в Жмеринському районі (1 412,9 грн.). Найвище середнє значення показника капітальних видатків на 1 мешканця характерне для сільських територіальних громад Вінницького району (33,1 грн.), тоді як найнижче значення цього показника притаманне Могилів-Подільському району (7,1 грн.).

Високий рівень дотаційності бюджетів сільських територіальних громад Жмеринського району $(35,7 \%$, середнє значення) найменш дотаційними є територіальні громади Тульчинського району $(4,3 \%)$. Частка місцевих податків і зборів у доходах загального фонду є високою у Могилів-Подільському районі $(45,7 \%)$, Гайсинському районі (45,5\%), Тульчинському районі $(43,6 \%)$.

Аналіз наявних програм та стратегій соціально-економічного розвитку ОТГ у різних регіонах України дав змогу визначити такі проблеми, недоліки та прогалини: громадам бракує програм розвитку малого й середнього бізнесу, планів зі створення нових робочих місць, проєктів місцевого розвитку; з різних причин ОТГ не використовують природні ресурси, розташовані на їхній території, у повному обсязі; більшість працездатного населення громад зайнята в особистому селянському господарстві; відсутність капітального та поточного ремонту доріг унеможливлює повноцінне функціонування громад, життя населення, задоволення соціальних потреб [8, с. 7].

На сучасному етапі чітко окреслюються дві тісно пов'язані проблеми. 3 одного боку, в українському селі потребує виконання великий обсяг організаційно-економічних заходів та матеріало- й трудомістких робіт зі створення й розвитку високопродуктивного сільського господарства, а з іншого боку, на селі наявні чимало трудових ресурсів, не зайнятих продуктивною працею [1, с. 12].

На думку авторів [9, с. 46], «проблеми криються також у кваліфікації управлінських кадрів щодо розподілу та адміністрування бюджету громади, безпідставному сподіванні на залучення грантів, інвестицій та коштів різних програм без стратегічного бачення перспектив розвитку та механізмів його забезпечення. Місцеве самоврядування передусім має спрямовувати діяльність ОТГ на організацію стратегічних соціально-економічних завдань, науково-технічних проєктів підприємств і організацій, розташованих на її території».

На основі вивчення літературних джерел визначено основні чинники життєдіяльності сільських територіальних громад (рис. 2).

Отже, в основі стратегії розвитку сільських територій лежить підвищення життєвого рівня сільського населення з використанням потенціалу території за державної підтримки ініціатив громади та активної участі місцевого самоврядування у створенні стимулів до збалансованого економічного та соціального розвитку регіонів.

Збалансований розвиток сільської території - це процес підвищення рівня та якості життя сільського населення, що сприяє урізноманітненню видів аграрної і позааграрної діяльності, продуктивній зайнятості, диверсифікації доходів сільських домогосподарств та наповненню бюджетів місцевих громад, соціальній захищеності мешканців, сучасному інфраструктурному розвитку поселенської мережі, збереженню й підвищенню родючості грунтів, захисту ландшафтів та біологічного різноманіття [5, с. 57]. 


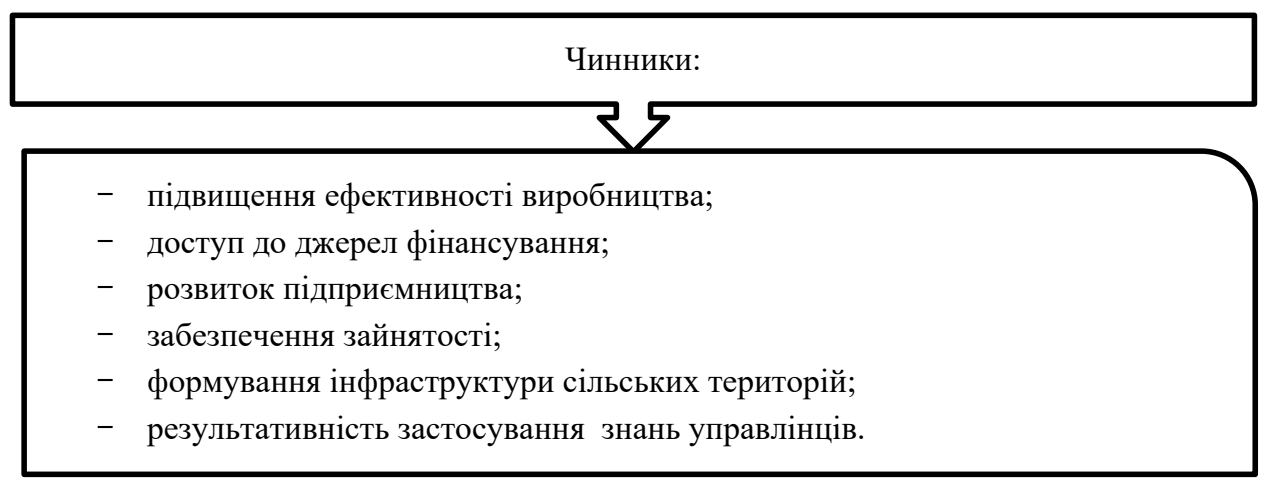

Рис. 2. Чинники впливу на життедіяльність

сільських об'єднаних територіальних громад

Джерело: сформовано автором на основі джерел $[1$, c. 11; 10, c. 74; 11, с. 8$]$

Отже, економічне зростання національної економіки визначається, зокрема, конкурентоспроможністю сільських територіальних громад і розвитком сільських територій.

Кожна територія має свої конкурентні переваги, що за умови застосування дієвих механізмів управління сприятимуть підвищенню конкурентоспроможності бізнесу, що розміщений на цих територіях [12, с. 48].

Висновки. Подальший розвиток об'єднаних територіальних громад, у тому числі сільських, в умовах реформи децентралізації залежить від ефективної державної політики, в основі якої лежить створення сприятливого середовища для вирішення економічних, соціальних і екологічних проблем територій та підвищення якості життя сільських мешканців. Результативність державної політики вимагає поєднання інтересів громади з напрямами розвитку сільських територій через активізацію підприємництва, розширення можливостей самореалізації громадян.

Забезпечення фінансової спроможності сільських територіальних громад $є$ умовою досягнення соціально-економічного розвитку та модернізації інфраструктури, при цьому досягнення такої спроможності можливе лише за налагодженого механізму наповнення дохідної частини бюджетів. Гарантування фінансової спроможності дасть змогу громаді впевнено розвиватися в майбутньому і прискорить процеси вирішення наявних проблем задля вдосконалення системи місцевого самоврядування в Україні.

\section{Список використаних джерел:}

1. Рябоконь В. Формування стійкої сільської поселенської мережі та об'єднаних територіальних громад. Економіка АПК. 2019. № 2. С. 6-18.

2. Конституція України. URL: https://www.president.gov.ua/ua/documents/constitution/konstituciya-ukrayinirozdil-хі (дата звернення: 10.09.2021).

3. Про заходи щодо впровадження Концепції адміністративної реформи в Україні : Указ Президента України. URL: https://zakon.rada.gov.ua/laws/show/810/98\#Tеxt (дата звернення: 12.09.2021).

4. Енциклопедія державного управління. URL: http://academy.gov.ua/NMKD/library_nadu/ Encycloped_vydanniy/ee797129-a005-496b-b86a-95045d0132cf.pdf (дата звернення: 30.09.2021).

5. Ходаківська О., Кононенко О. Еволюція економічних теорій сталого сільського розвитку. Економіка АПК. 2020. № 10. С. 49-61.

6. Децентралізація в Україні : офіційний сайт. URL: https://decentralization.gov.ua (дата звернення: 20.08.2021).

7. Літинська територіальна громада. URL: https://decentralization.gov.ua/newgromada/2024 (дата звернення: 15.09.2021). 
8. Хвесик М., Ільїна М. Параметризація оцінювання перспектив розвитку сільських територій різних типів. Економіка АПК. 2019. № 6. С. 6-14.

9. Россоха В., Плотнікова М. Розвиток сільських територій України в умовах децентралізації управління: стан, проблеми, перспективи. Економічний дискурс. 2018. Вип. 4. С. 41-53.

10. Юхименко П., Паска І., Загурський О. Економічний підхід щодо формування людського капіталу в системі управління сільськими територіями. Економіка АПК. 2019. № 3. С.71-78.

11. Зінчук Т., Патинська-Попета М. Управління фінансовим потенціалом об'єднаних територіальних громад. Економіка АПК. 2019. № 12. С. 6-15.

12. Іртищева I., Надточій І., Мураховська Л. Регіональне управління бізнес-процесами в умовах децентралізації влади в Україні. Украӥнський журнал прикладної економіки. 2021. Т. 6. № 2. C.48-55.

\section{References:}

1. Ryabokon V. (2019) Formuvannia stiikoi silskoi poselenskoi merezhi ta obiednanykh terytorialnykh hromad [Formation of a stable rural settlement network and united territorial communities]. Economics of AIC, no. 2, pp. 6-18.

2. The Constitution of Ukraine. Available at: https:/www.president.gov.ua/ua/documents/constitution/konstituciya-ukrayini-rozdil-xi (accessed 10 September 2021).

3. Decree of the President of Ukraine "On measures to implement the Concept of administrative reform in Ukraine". Available at: https://zakon.rada.gov.ua/laws/show/810/98\#Text (accessed 12 September 2021).

4. Encyclopedia of Public Administration. Available at: http://academy.gov.ua/NMKD/library nadu/Encycloped_vydanniy/ee797129-a005-496b-b86a-95045d0132cf.pdf (accessed 30 September 2021).

5. Khodakivska O., Kononenko O. (2020) Evoliutsiia ekonomichnykh teorii staloho silskoho rozvytku [Evolution of economic theories of sustainable rural development]. Economics of AIC, no. 10, pp. 49-61.

6. Decentralization in Ukraine: official site. Available at: https://decentralization.gov.ua (accessed 15 August 2021).

7. Lityn territorial community. Available at: https://decentralization.gov.ua/newgromada/2024 (accessed 15 September 2021).

8. Khvesyk M., Ilyina M. (2019) Parametryzatsiia otsiniuvannia perspektyv rozvytku silskykh terytorii riznykh typiv [Parameterization of assessment of prospects for development of rural areas of different types]. Economics of AIC, no. 6, pp. 6-14.

9. Rossokha V., Plotnikova M. (2018) Rozvytok silskykh terytorii Ukrainy v umovakh detsentralizatsii upravlinnia: stan, problemy, perspektyvy [Development of rural areas of Ukraine in terms of decentralization of management: status, problems, prospects]. Economic Discourse, vol. 4, pp. 41-53.

10. Yukhimenko P., Paska I., Zagursky O. (2019) Ekonomichnyi pidkhid shchodo formuvannia liudskoho kapitalu v systemi upravlinnia silskymy terytoriiamy [Economic approach to the formation of human capital in the management system of rural areas]. Economics of AIC, no. 3, pp. 71-78.

11. Zinchuk T., Patinska-Popeta M. (2019) Upravlinnia finansovym potentsialom obiednanykh terytorialnykh hromad [Management of financial potential of united territorial communities]. Economics of AIC, no. 12, pp. 6-15.

12. Irtyshcheva I., Nadtochiy I., Murakhovskaya L. (2021) Rehionalne upravlinnia biznes-protsesamy v umovakh detsentralizatsii vlady $\mathrm{v}$ Ukraini [Regional management of business processes in the context of decentralization of power in Ukraine]. Ukrainian Journal of Applied Economics, vol. 6 , no. 2, pp. $48-55$. 